\title{
Applying Landscape Science to Natural Resource Management
}

\author{
Guy M. Robinson ${ }^{1}$ and Doris A. Carson ${ }^{1}$
}

ABSTRACT. This is the introduction to the Ecology and Society special feature on "Applying Landscape Science to Natural Resource Management". Primarily drawing upon examples from Australia, the nine papers in the feature illustrate how landscape science seeks to integrate information from diverse sources to generate management solutions for implementation by individual land managers, communities, and governments at different levels. This introduction refers to the genesis of the feature, briefly outlines the nature and content of landscape science, and then summarizes key features of the nine papers. These are organized into two sections: one deals with inputs from human agents in the landscape, and one with the development of models enabling different management scenarios and environmental changes to be envisaged, understood, and applied to policy development.

Key Words: Australia; landscape science; modeling; natural resource management (NRM); stakeholder integration

\section{INTRODUCTION}

Initial impetus for this special feature came from discussions during the Place and Purpose Symposium held in Adelaide in December 2009 as part of the Surveying and Spatial Sciences Institute Biennial Conference. The theme for several sessions at the Symposium was "Applying Landscape Science to Natural Resource Management", convened by Professor Wayne Meyer, Director of the Landscape Futures Program at the University of Adelaide, and organized on behalf of the South Australian Landscape Science Cluster. The Symposium featured two days of presentations, the first day being designed to highlight the context, experiences, and new developments in tools and processes being applied in regions around Australia. This featured the application of remote sensing to assist planning and monitoring in regions. The second day brought national and international perspectives to the developing science of integrated landscape management, complemented by presentations on new technical developments and tools that can be applied to better plan and manage complex regional systems.

The rationale was to include presentations focusing on the research and implementation challenges for changing land uses in regional social-ecological systems. The broad aim of the research being addressed was to achieve a better and more renewable balance between commercial production and conservation of native ecosystems in Australia. Hence this aim similarly underpins the papers in this special feature, namely the tension that exists between production and conservation, especially (but not exclusively) in regions where land use is dominated by agricultural production. It is essentially within this agricultural setting that all the major issues of ecology and society considered herewith are being expressed.

The basic objective of the various papers in this feature is to examine the interconnections between the environment, the social setting and resultant tensions in considering how changes to land use can achieve multiple benefits. Therefore the papers bring together management, policy, and societal issues which must be understood to enable different land users, locales, and regions to adapt to a myriad of future challenges. In particular, research in this area is focusing on development of integrated assessment methods and new methodologies to help conceptualize and represent the land use system. These advances in research include work on vulnerability assessments for different scenarios, landholder attitudes towards land use change, and policy development implications of various changes.

This is research which engages directly with the interests of rural society by identifying processes and actions to assist communities in adapting to the growing pressures of increasing population and limited resource availability at a variety of spatial scales set alongside changing societal expectations. It is an extremely challenging interplay between biophysical, societal, and policy elements seen in this feature through the lens of a series of examples drawn primarily from the Australian context where the effects of persistent drought across large parts of the country raise questions of the longterm viability of small communities and production systems. Given this Australian context the research has also examined the increasing efforts to involve traditional land owners in land management within a delicate socio-cultural Indigenous context.

\section{LANDSCAPE SCIENCE}

In recent years the term "landscape science" has been employed to refer to research that seeks to understand the relationship between people and their environment, with a focus on land use change and data pertaining to land resources at the landscape scale. It has its origins in different branches of academia, including the natural sciences (in the form of landscape ecology) (Wiens et al. 2007), the human sciences (through human geography and human ecology) (Steiner 2008), and humanistic and symbolic approaches to landscape (Cosgrove and Daniels 1988). It deals with the understanding 
of relevant structures, processes and their states and drivers primarily in terms of anthropogenic uses of landscapes. Therefore landscape science can be regarded as a metadiscipline, which has evolved from the synergistic application of theories, methods and knowledge of several scientific disciplines being applied to study landscapes, including agricultural science, forestry science, conservation science, geoscience, biology, the social sciences, engineering sciences, and mathematics. Landscape science includes or addresses the following (Antrop 2000):

- environmental, economic, and social processes induced by land use or land use changes

- spatial interactions of processes and driving forces in anthropogenic landscapes

- studying multiscale processes and cross-scale dynamics

- spatial data analysis and modeling

- landscape systems analysis and landscape modeling (for example, scaling approaches, scenario techniques, indicator identification, complexity reduction)

- discrete and integrated impact assessment of land use

- methods and understanding of participatory approaches for land use development and decision-making in land management

- fundamentals and tools for decision support systems as well as providing scientific methods in decision implementation of landscape management

- multi- and interdisciplinary approaches and transdisciplinary studies.

This content is closely related to that of "land system science", which also refers to "an interdisciplinary field [that] seeks to understand the dynamics of land cover and land use as a coupled human-environment system to address theory, concepts, models, and applications relevant to environmental and societal problems, including the intersection of the two" (Turner II et al. 2007, p. 20666). In assessing the prospects for the future development of land system and landscape science, Rounsevell et al. (2012) refer to the challenge posed by the multi- and interdisciplinary nature of much of this research, which seeks to bridge the nature-society divide (Bloemers et al. 2010). Hence, researchers need to consider the behavior of people and communities, multilevel decision-making affecting multifaceted land units, and the contexts within which decisions are made and in which the land itself exists (Lambin et al. 2006).

Empirical analysis of land use change has been a common approach often focusing on particular problems associated with human-environment interactions, including changing land-use practices and associated changes in land cover (e.g., deforestation), responses to climate change and impacts of various environmental changes on agriculture, forestry, biomass production, and ecosystem functioning (e.g., Haberl et al. 2001, Mooney et al. 2009). These analyses are often accompanied by the application of modeling land system dynamics, generally involving structural analysis of complex interactions within the land system. Models have been used to explore the behavior of systems, to make ex-ante assessments of policies, inputs to the planning process, and scenario creation (e.g., Matthews et al. 2007, Rounsevell et al. 2006, van Ittersum et al. 2008). Rounsevell et al. (2012) argue that new models will be needed that go beyond single sector foci to capture the complexity of human-environmental interactions across different scales (e.g., Gaube et al. 2009). However, there are various modeling strategies that can be adapted to meet this challenge, including economic models (e.g., Lee et al. 2005), models integrating socio-economic and environmental processes (Leimbach et al. 2012), and agentbased modeling for simulating complex decision-making (for example, Murray-Rust et al. 2011).

In seeking to understand recent developments in landscape science and the content of this feature, lessons can be learnt from the four-year program of the Australian Government's Commonwealth Environmental Research Facilities program, launched in 2005 (see also Pedroli et al. [2006] for a European perspective). This funded eight research hubs in its first round, one of which, Landscape Logic, features in the book of the same title by Lefroy et al. (2012). Its subtitle "Integrating science for landscape management" hints at the overall concern of the program and its hubs, namely to bring together understanding about landscape from various perspectives and disciplines, capturing multifaceted knowledge of places, processes and people as a basis for management. The starting point for this work is the assembly of data, both quantitative and qualitative, with which to understand the complex, nonlinear processes that frequently produce systems operating at or understandable at a landscape scale. However, an ongoing problem, also highlighted frequently in studies on climate change, is "the lack of long-term data capable of showing the state of the environment and the direction in which it is heading" (p. 3). Hence despite the frequent availability of data in various forms, interpretation and analysis must necessarily involve innovative ways of combating the different forms, including surrogates for historic and prehistoric changes, and modeling that can both provide estimates for missing data and generate management scenarios.

The Landscape Logic project focused on knowledge discovery, integration and broking, the latter intending to generate desirable management outcomes, explicitly involving the knowledge possessed by landholders and managers in addition to that from scientists and stakeholders in industry and government. It is worth repeating the five basic components within the project's systems thinking because 
these are dominant in the papers in this special feature of Ecology and Society:

- Research involves clearly defined, measurable, and widely accepted end points, including both environmental and socio-economic goals.

- The system boundaries are large enough to incorporate the major factors whilst not attempting to encompass all external devices.

- Research articulates each of the major influences acting on the variables of interest.

- It identifies major factors providing appropriate or sufficient measurement of the effect of one major variable on another.

- Data collection is at sufficient spatial and temporal resolution to test relationships.

\section{Landscape science and natural resource management in Australia}

This feature comprises nine papers that apply landscape science to natural resource management (NRM) in Australia, where the term NRM generally refers to a particular set of natural resources rather than the entire spectrum, and in particular it has been applied to management associated with agriculture and protected areas, rather than other industries such as mining. This term's usage has its roots in the late $19^{\text {th }}$ century in North America in concerns with understanding the ecological nature of the rangelands, and the growth of a conservation movement at that time (Conacher 1986). In most other Developed Countries the term agri-environment programs or policies has been employed more frequently than NRM, though the two terms are often used synonymously. The focus of NRM on agriculture also reflects agriculture's significant economic role in Australia: it contributes 20 per cent of the country's exports by value; it consumes 70 per cent of the water; and it accounts for around three-quarters of the land resources (Aplin 1998). Enough food is produced to feed 55 to 60 million people in a country whose population is only just over 20 million. Farmers, graziers, Indigenous communities, and other private land managers producing food and fiber manage approximately 77 per cent of the land area.

The papers herewith provide good exemplars of the current range of work applying landscape science to NRM in Australia, and highlight some of the specific problems encountered within the Australian context. Two aspects are dominant: the development of methods that can combine "hard" scientific data with input of a qualitative nature from landholders, land managers and other community stakeholders; and the use of a variety of models to aid both an understanding of how landscapes can be managed and to develop management scenarios that can take account of environmental change. The papers start with those that emphasize the need to mesh hard and soft data, and then subsequently concentrate on use of various models and scenario development.

Involving stakeholders

Landscape scientists generally work closely with individual land managers, rural communities, groups, and individuals who have a role to play in managing the environment. Yet the knowledge possessed by these stakeholders is not always highly regarded by either researchers or policy makers. In an examination of different environmental management projects that aimed to integrate knowledge from different sources, Raymond et al. (2010) concluded that integration of stakeholder knowledge was inherently complex, usually dealt with in arbitrary fashion and with a variety of knowledge integration perspectives employed by different researchers. They and others have concluded that Western paradigms and systems of knowledge are not readily able to deal with the full complexity of environmental management, nor sufficiently able to integrate local stakeholder perspectives in the development of environmental management strategies (Ludwig et al. 2001, Olsson and Folke 2001).

Yet widespread recognition of this problem has led to development of new approaches to environmental management, under various different guises, such as community-based NRM (Robinson 2008), sustainability science (Clark and Dickson 2003), and adaptive comanagement (Armitage et al. 2009, Berkes 2009). These approaches all share certain characteristics (Raymond et al. 2010). They recognize the need to integrate knowledge held by academic researchers (often across traditional academic disciplinary boundaries) and nonacademic participants; they highlight the need to build on different (and sometimes disparate) bodies of knowledge to address a research or applied question by developing shared theory, methods and new knowledge to promote common understanding of environmental management problems; they often utilize participatory research methods and seek to facilitate participatory, multilevel governance processes to both enhance the validity of knowledge elicited in research and to increase inclusiveness of stakeholders in decision-making; they follow iterative processes of knowledge creation, application, reflection, learning and feedback to science or decision-making; and they attempt to integrate knowledge across a variety of spatial and temporal scales. These characteristics are all present in various ways in the first four papers in this issue and have become an integral component of landscape science.

Hatton MacDonnald et al. (2013) focus on input to NRM from community stakeholders. Given the variety of individuals and organizations within a community that may have views on NRM or who have the capacity to influence decision-making on resource management issues, it is vital to understand the 
diversity of views represented. Increasingly, both consultation with the community and direct input to decision-making are being mandated in the NRM process by government, as Hatton MacDonnald et al. (2013) illustrate with respect to the operation of NRM boards in South Australia, catchment management authorities and other local environmental management bodies. They note that there is a growing body of work focusing on different aspects of community engagement, including assessments of successful engagement, the nature of participants' approaches, and analysis of particular types of stakeholders (Lengwiler 2008, Newig et al. 2008, Reed 2008). Their contribution to work on this subject is a focus on the values of stakeholders contributing to the South Australian Murray-Darling Basin NRM Board. In particular, they contribute a qualitative methodology aimed at helping policy-makers and scientific advisers to understand the values forming the advice provided by community leaders.

The method adopted involved semistructured in-person interviews with community stakeholders to address what seems like a disarmingly simple question: "What do NRM stakeholders value in the environment?" Reliance on a qualitative methodology highlights the oft-quoted difference between the "hard" scientific information generally relied upon by scientists and policy-makers and the greater use of "soft" qualitative information in the social and behavioral sciences. They used an approach in which values are linked to specific places (Raymond et al. 2009), enabling the research team to demonstrate that when a particular ecosystem service directly impacts the viability or enjoyment of the community the more likely the community advisors are to support the management and preservation of that service. However, this also means that some ecosystem services categories can be overlooked. Environmental goals were seen dominantly in the context of a sustainable and active community. Hence, policies viewed as falling outside a group's or individual's ambit tended to be regarded as ones in which they did not have a direct stake and this could affect their advice and input.

Zander's (2013) paper also discusses a participatory process, in this case to manage protected areas in the Northern Territory where responsibility for management is shared between NRM agencies and the Indigenous landowners. Zander focuses on how Indigenous groups can be compensated for providing environmental services. In a sample survey of around 400 respondents across urban Australia, questions were asked about preferences for a set of hypothetical scenarios. These described support for Indigenous NRM that yielded certain environmental and social benefits. Costs for each scenario were indicated that would be borne hypothetically by respondents, but with environmental benefits deemed to accrue to the whole of Australian society. This choice experiment survey draws on the notion of payments for environmental services as have been applied in other parts of Australia (Connor et al. 2008) and recommended for
Indigenous-held land in northern Australia (Pearson and Gorman 2010).

In this case the survey focuses on society's willingness to pay and the benefits accruing to society as a whole from Indigenous management. Zander's research found that the majority of respondents were willing to pay for Indigenous NRM. Positive responses were related to the belief that funds accruing would contribute to maintaining a healthy environment (e.g., through the control of feral animals and weeds or the reduction of greenhouse gas emissions), maintaining Indigenous culture or providing Indigenous employment. Yet the survey identified some level of ignorance of the potential social benefits of Indigenous involvement in NRM, as well as of key environmental issues such as the critical role of fire management. This paper also considers issues relating to raising voluntary payments to finance Indigenous NRM and key differences in responses between men and women and northern and southern parts of the country. Overall it represents a baseline survey of public understanding of issues on Indigenous NRM and the potential for implementing publically-funded schemes to support Indigenous NRM.

Stacey et al. (2013) examine collaborative ways of measuring the performance of jointly managed protected areas in northern Australia. They propose a new way of measuring and evaluating the effectiveness of joint management approaches between Indigenous owners and NRM agencies in protected areas. The researchers employed a participatory action research approach to monitoring and evaluating joint management. The project involved the joint identification of a set of common performance indicators for evaluation, which emphasizes the importance of social relationships within this particular (Indigenous) NRM context. Common indicators related to the performance in governance and decisionmaking, application and interpretation of cultural heritage and traditional ecological knowledge, expansion of social capital, human and financial resources, and visitors, with little emphasis on the biophysical outcomes of management. The performance indicators were largely process- rather than outcome-oriented, reflecting the need to better integrate Indigenous stakeholders in the management and evaluation process, rather than imposing rigid outcome measures on them. The participatory process itself is seen as important in its own right, and crucial in terms of developing and measuring the indicators.

Raymond and Cleary (2013) present a practical assessment tool that has been used in facilitating community capacity building and social learning for NRM. They view the tool as an example of action-oriented approaches to support social and ecological sustainability, and hence the tool is part of a spectrum that includes participatory action research (as used by Stacey et al. 2013), adaptive comanagement and community-based NRM (Fabricius 2004, Gonsalves et al. 
2005, Marshall 2009). The tool includes systematic selfassessment and perceptions of community capacity for planning and delivering NRM programs across multiple scales of management. It was developed in conjunction with the South Australian Arid Lands NRM Board, drawing upon input from board members and community participants. Key aspects include the identification of community capacity indicators and developing scoring rubrics (see also Minkler et al. 2008, Nelson et al. 2010a,b). The overall premise of this work is that community participation is crucial in identifying strengths, weaknesses and gaps in NRM capacity, and that both "expert" views and those of practitioners (in this case landholders) need to be included when addressing capacity. The paper also considers limitations of the tool and the research process utilized in this particular example. However, there are various positives and lessons from this work that can be applied in not only an NRM context but also others, including climate change, community development and regional development.

Mendham et al. (2012) focus on one particular set of stakeholders, landholders, in examining the impact of property turnover in parts of rural Victoria, their study areas enabling contrasts to be drawn between districts close to the state capital Melbourne, where in-migration and urban sprawl are occurring, and those further north and west where populations are declining but where large-scale broad acre farming is accompanied by some tourism and conservation of amenity landscapes. The authors consider the challenges posed to NRM by property turnover in their study area. Their research engages with some of the key changes affecting farming across the Developed World, including the high and rising mean age of farmers (Mendham and Curtis 2010), the falling rate of intergenerational transfer of properties (Barr 2004), and the growing potential for sales of rural property to non-farming members (Lockie et al. 2006). This is concentrating farmbased production in fewer hands across large areas. Meanwhile, in rural-urban fringes and especially in scenically attractive locales, in-migration is leading to subdivision and substantive restructuring of rural landscapes (Gosnell and Travis 2005, Walford 2003). In some cases this has involved growth in hobby or part-time farming (e.g., Holloway 2002; Stobbe et al. 2009), in others changes to land use and production orientation (Jackson-Smith et al. 2005) and a rising proportion of absentee owners or "weekend farms" amongst newcomers. Yet newcomers often have less experience of NRM issues and NRM programs such as Landcare. Such changes are underpinned by differences between traditional landholders and newcomers which are also being manifest in decisions by new land managers generating significant ecological consequences reflecting different attitudes towards conservation, native flora and fauna, and production systems (Raymond et al. 2011, Waudby et al. 2012).

Drawing on a large survey of rural landholders the research by Mendham and colleagues (2012) reveals high levels of property turnover (one quarter of all properties in a ten-year period) representing a dramatic change in the ownership pattern. The new landholders are shown to have different values, knowledge, sources of information, attitudes, and management practices compared with the long-term land managers. Where newcomers purchased property primarily for farming purposes this often resulted in increased investment and decisions taken designed to ensure profitable business and decent return on that investment. However, new owners also tended to look more favorably on management favoring conservation. This cohort of new owners, many of whom are absentees, complicates decision-making regarding land management and may have major implications for NRM. In seeking to understand these implications, landscape scientists need to engage effectively with the newcomers, identifying them through regular reviews of local government ratepayer databases and interviewing them to understand their knowledge, attitudes, and behavior.

One way in which interactions between human agents and the environment have been conceptualized recently has been through the concept of ecosystem services whereby the focus of research is on how natural and seminatural ecosystems provide benefits to people. These benefits were formally categorized in 2005 by the United Nations Millennium Ecosystem Assessment, which recognized four broad categories: provisioning (food and water), regulating (controlling climate and disease), supporting (nutrient cycles, crop pollination), and cultural (recreational and spiritual) (Millennium Ecosystem Assessment 2005). Research has grown rapidly on these services, in terms of their ecology, measurement, evaluation and economic implications (Kareiva et al. 2011, McNeeley et al. 2009, Ninan 2010). Hence, work on ecosystem services has become a key component of landscape science.

In this collection, one paper deals explicitly with ecosystem services and their recognition by the community. Petter et al. (2013) focus on mapping ecosystem functions as a means of supporting assessments of ecosystem services. In a trial in south-east Queensland they used various elements of biophysical data for 19 different ecosystem functions, mapping each one to provide support for land use and NRM policy and planning. Identification and mapping of the functions were performed with input from stakeholders selected via a steering group, a working group, expert panels, and community workshops, focusing on structure, terminology, and tools. This involvement of the community helped cover different scales of information and also different forms of knowledge across sectors and disciplines. Some of the datasets selected existed already but others had to be compiled by combining pre-existing data. Datasets were overlain in a geographical information systems (GIS) environment and subject to stakeholder peer review to produce a total ecosystem function map. 
The paper reports on the process of constructing the maps and details key issues arising, including the extent of spatial overlap of datasets, the identification of hotspots of coastal and marine ecosystem functions and the limitations of this approach. Essentially the adopted method aimed to provide information that was sufficiently place-based and credible to meet the needs of the key decision-makers. By producing an iterative process of data collection, analysis, and review, the researchers produced robust data layers that could be used directly as input to government policy for the region. As a method this approach is relatively unsophisticated when compared with some of the modeling used in other papers in this collection, but it can be applied relatively easily in different regions as it identifies the key ingredients required. Moreover, it is nonproscriptive in that stakeholders can apply information to management practices related to their own capacities.

\section{Developing models}

Modeling has been a central part of landscape science, generally attempting to capture complex interactions between people and the environment to arrive at information to assist evaluation of policy outcomes or develop new policy prescriptions. Models used in landscape science generally employ physical, mathematical, or numerical approaches to help develop better understanding of existing processes and interactions and to estimate "what if?" scenarios, as in the application of a new policy or land management activity. Provision of environmental data in various forms is central to such models, with decision-makers needing information systems that can integrate large and diverse datasets and also provide tools for analyzing and visualizing key information. This section includes three papers that employ models of different types, all focusing on human-environment interaction but employing different modeling strategies to reach conclusions.

Parrott et al. (2012) use examples from forest, marine, and agricultural systems to show how modeling of these systems can be used to represent linkages across different scales and between subsystems. Two of the applications are drawn from Canadian case studies whilst the third relates to work on biodiversity conservation in the Eyre Peninsula, South Australia. The models presented in this paper are hybrids that integrate the use of GIS with agent- or individual-based approaches in which the basic modeling units are entities such as individual stakeholders, individual animals or plants, or highly resolved landscape units. Simulations then focus on processes "from the bottom up" that can reflect collective actions and capture the characteristics of complex systems by drawing on Ostrom's (2009) conceptual framework for describing and analyzing social-ecological systems.

The examples include a forest-based model, testing the effect of different management plans on long-term evolution of animal populations in the context of the activities of logging companies in the Côte-Nord region of Quebec. In the Saint Lawrence Estuary in Quebec a model was used to explore responses to management that must balance the natural resources of the main ecosystems, marine life, and tourists. The third model explores the resilience and adaptive capacity of the Eyre Peninsula region in face of various challenges. It encompasses a network of interactions between governance system agencies and users, and was developed using information gathered from key informants in interviews. Satellite remote sensing is used to gather data on distribution of native vegetation, and location of farms is also plotted. Hence, this is a coupled social-ecological network in which different types of change can be modeled and "what if" scenarios explored. The model's incorporation of "bottom up" and non-linear information enables it to focus on questions difficult to answer with more standard methods. This is characteristic of all three case studies presented by Parrott et al. (2012) whose arguments champion both the bottom up component and modeling of interactions between social and ecological systems. The participatory component of bottom up is deemed to be crucial to the models' effectiveness and enables multiple perspectives to be incorporated (e.g. Prell et al. 2007). The paper also champions the notion of establishing "envelopes" of probable future states (Parrott and Meyer 2012) in which decision-making and policies are designed to maintain the landscape within a desired range or envelope.

Thackway et al. (2013) use modeling to examine NRM decision-making for two case studies involving management of fire and soil erosion. The key to the model is use of satellitebased time series information that provides data on dynamic changes in land cover. It is argued that these data sets are crucial in any framework for managing information needs of NRM decision-makers, with multitemporal image products having major advantages over single images when it comes to investigating land cover, which can change constantly even from day to day. The paper advocates combining imagery from multiple satellites with field-based data in the form of a fivestep approach, which introduces biophysical information to add value to the imagery. Using case studies from northern Australia and the Australian rangelands, the paper illustrates the effectiveness of combining information as advertised for use by national policy decision-makers, regional reporting decision-makers and land managers. It also acknowledges that decision-makers need information at key decision points in time and that a full suite of relevant data needs to be provided in timely and succinct form to properly support decisionmaking processes. This is a key challenge for government at all levels and research organizations to meet.

Paterson and Bryan (2012) tackle an issue that has been of growing concern over the past decades, namely the impact on landscape and NRM caused by policies designed to produce environmental benefits in conjunction with maintenance of 
productive farming and forestry. Such policies have been widespread from the mid-1980s in the European Union, following the creation of Environmentally Sensitive Areas (Hanley et al. 1998, Wilson et al. 2007), and in the United States, where the Conservation Reserve Program (Rao et al. 2007, Sullivan et al. 2004) and farmland preservation schemes have a long history (Dorfman et al. 2009, Hellerstein and Nickerson 2002). In recent years such measures have increasingly been linked directly to policy on climate change, and especially reductions in production of greenhouse gas emissions (Palm et al. 2010). In this paper the effects of payments on the adoption of reforestation in agricultural areas is investigated, examining a scheme aimed at promoting carbon sequestration. However, this reduces the amount of land available for agricultural production and so may lead to reduced output and rising food prices. Hence there needs to be a food-carbon trade-off (Crossman et al. 2011), which can be quantified using either scenario analysis (Bryan et al. 2011) or modeling of the efficiency of land-use combinations for spatially explicit land use arrangements (Nelson et al. 2009, Polasky et al. 2008).

Working in the lower reaches of Australia's Murray-Darling Basin, Paterson and Bryan (2012) quantified food-carbon trade-off curves at a landscape scale employing two commonly used market-based carbon policy instruments, namely payments per tonne and payment per hectare. Their analysis reveals that large areas of agricultural land could become more profitable as carbon sinks even with relatively modest carbon prices. However, this depends on a number of assumptions made in the calculations and so it is not reliable to extrapolate directly to predictions of reforestation under a carbon market. It does reveal, though, that efficient policy design can introduce reforestation to sequester significant amounts of carbon with minimal impacts on overall agricultural output. Variations in impact and both positive and negative outcomes associated with payment per tonne and payment per hectare are examined. The limitation of this work is that it focuses on economic profitability only, which the authors note may not be the only consideration of landholders. Hence decisionmaking factors need to be addressed to better understand likely responses to further policy initiatives promoting reforestation. Moreover, there are other cobenefits and trade-offs that could be addressed, such as reduced soil erosion, energy security, and regional development.

\section{CONCLUSION}

The papers in this collection provide a window into the state of the art of landscape science, and especially its practice in Australia. In broad terms they collectively demonstrate that in order to develop policy that can produce future landscapes capable of meeting multiple goals and satisfying demands from various stakeholders the inputs from a broad spectrum of disciplines need to be incorporated. Yet this multiplicity needs to extend beyond academe to inputs from land managers and communities affected by policy so that participation in the research process and in formulating policy can encompass a wide variety of individuals and groups. This means that scientists' preference for reliance on "hard" data and numerically-based models has to be tempered by allowance for other inputs to models and landscape analysis. This provides scope for some of the innovative approaches utilized in the papers herewith, including participatory action research and the incorporation of qualitative data as an integral component of analysis. In future research there must also be a greater awareness of the need to engage directly with policymakers. This can be achieved by having policy-makers embedded within the research process rather than as recipients of research findings or as commentators on modeled scenarios. Carefully thought out designs that incorporate knowledge exchange between stakeholders must be part of a new paradigm in which researchers take responsibility for engaging with policy-makers and politicians in ways that can break down traditional barriers and entrenched mindsets. Given the rapidity with which landscape science has evolved in the past two decades there can be much hope that such paradigm shifts and new frameworks within which landscape science research develops can be achieved.

Responses to this article can be read online at: http://www.ecologyandsociety.org/issues/responses. php/5639

\section{LITERATURE CITED}

Antrop, M. 2000. Geography and landscape science. Belgian Journal of Geography. Belgeo special issue. 29th International Geographical Congress 1/4: 9-35.

Aplin, G. 1998. Australians and their environment: an introduction to environmental studies. Oxford University Press, Melbourne, Australia.

Armitage, D., R. Plummer, F. Berkes, R . I. Arthur, A. T. Charles, I. J. Davidson-Hunt, A. P. Diduck, N. C. Doubleday, D. S. Johnson, M. Marschke, P. McConney, E. W. Pinkerton, and E. K. Wollenberg. 2009. Adaptive co-management for social-ecological complexity. Frontiers in Ecological Environments 7(2): 95-102. http://dx.doi.org/10.1890/070089

Barr, N. 2004. The micro-dynamics of change in Australian agriculture 1976-2001. Australian Bureau of Statistics, Canberra, Australia.

Berkes, F. 2009. Evolution of co-management: role of knowledge generation, bridging organisations and social learning. Journal of Environmental Management 90(5): 1692-1702. http://dx.doi.org//10.1016/j.jenvman.2008.12.001 
Bloemers, T., S. Daniels, G. Fairclough, B. Pedroli, and R. Stiles. 2010. Landscape in a changing world: bridging divides, integrating disciplines, serving society. Science Policy Briefing 41(October). European Science Foundation, Strasbourg, France. [online] URL: http://edepot.wur. $\underline{\mathrm{nl} / 161371 .}$

Bryan, B. A., N. D. Crossman, D. King, and W. S. Meyer. 2011. Landscape futures analysis: assessing the impacts of environmental targets under alternative spatial policy options and scenarios. Environmental Modelling and Software 26(1): 83-91. http://dx.doi.org/10.1016/j.envsoft.2010.03.034

Clark, W.C., and N. M. Dickson. 2003. Sustainability science: the emerging research program. Proceedings of the National Academy of Science 100(14): 8059-8061. http://dx.doi. org/10.1073/pnas.1231333100

Conacher, A. J. 1986. Environmental conservation. Pages 315-339 in D. N. Jeans, editor. Australia - a geography. Sydney University Press, Sydney, Australia.

Connor, J. D., J. Ward, C. Clifton, W. Proctor, and D. Hatton MacDonald. 2008. Designing, testing and implementing a trial dryland salinity credit trade scheme. Ecological Economics 67(4): 574-588. http://dx.doi.org/10.1016/j.ecolecon.2008.01.020

Cosgrove, D., and S. Daniels, editors. 1988. The iconography of landscape: essays on the symbolic representation, design and use of past environments. Cambridge University Press, Cambridge, UK.

Crossman, N. D., B. A. Bryan, and D. M. Summers. 2011. Carbon payments and low cost conservation. Conservation Biology 25(4): 835-845. http://dx.doi.org/10.1111/ j.1523-1739.2011.01649.x

Dorfman, J. H., B. J. Barnett, J. C. Bergstrom, and B. Lavigno. 2009. Searching for farmland preservation markets: evidence from the southeastern U.S. Land Use Policy 26(1): 121-129. http://dx.doi.org/10.1016/j.landusepol.2008.02.011

Fabricius, C. 2004. Rights, resources and rural development: community-based Natural Resource Management. Earthscan, London, UK.

Gaube, V., C. Kaiser, M. Wildenberg, H. Adensam, P. Fleissner, J. Kobler, J. Lutz, A. Schaumberger, J. Schaumberger, B. Smetschka, A. Wolf, A. Richter, and H. Haberl. 2009. Combining agent-based and stock-flow modelling approaches in a participative analysis of the integrated land system in Reichraming, Austria. Landscape Ecology 24(9): 1149-1165. http://dx.doi.org/10.1007/ s10980-009-9356-6

Gonsalves, J., T. Becker, A. Braun, D. Campilan, H. De Chavez, E. Fabjer, M. Kapiriri, J. Rivaca-Caminade, and R. Vernooy, 2005. Participatory research and development for sustainable agriculture and natural resource management.
International Development Research Centre, Ottawa, Canada.

Gosnell, H., and W. R Travis. 2005. Ranchland ownership dynamics in the Rocky Mountain West. Rangeland Ecology and Management 58(2): 191-198. http://dx.doi.org/10.2111/1551-5028 (2005)58<191:RODITR > 2.0.CO;2

Haberl, H., S. Batterbury, and E. Moran, editors. 2001. Using and shaping the land. Land Use Policy 18(1): 1-91. http://dx. doi.org/10.1016/S0264-8377(00)00040-5

Hanley, N., D. McMillan, R. E. Wright, C. Bullock, I. Simpson, D. Parsisson, and R. Crabtree. 1998. Contingent valuation versus choice experiments: estimating the benefits of environmentally sensitive areas in Scotland. Journal of Agricultural Economics 49(1): 1-15. http://dx.doi.org//10.1111/ j.1477-9552.1998.tb01248.x

Hatton MacDonald, D., R. Bark, A. MacRae, T. Kalivas, A. Grandgirard, and S. Strathearn. 2013. An interview methodology for exploring the values that community leaders assign to multiple-use landscapes. Ecology and Society 18(1): 29. http://dx.doi.org/10.5751/ES-05191-180129

Hellerstein, D., and C. Nickerson. 2002. Farmland protection programs: what does the public want? Agricultural Outlook 291: 27-30.

Holloway, L. 2002. Smallholding, hobby-farming and commercial farming: ethical identities and the production of farming spaces. Environment and Planning A 34(11): 2055-2070. http://dx.doi.org/10.1068/a34261

Jackson-Smith, D., U. Krueter, and R. S. Krannich. 2005. Understanding the multidimensionality of property rights orientations: evidence from Utah and Texas ranchers. Society and Natural Resources 18(7): 587-610. http://dx.doi. org/10.1080/08941920590959578

Kareiva, P., H. Tallis, T. H. Ricketts, G. C. Daily, and S. Polasky. 2011. Natural capital: theory and practice of mapping Ecosystem Services. Oxford University Press, New York, USA.

Lambin, E. F., H. J. Geist, and R. R. Rindfuss. 2006. Introduction: local processes and global impacts. Pages 1-8 in E. F. Lambin, and H. J. Geist, editors. Land-use and landcover change: local processes and global impacts. SpringerVerlag, Berlin, Germany. http://dx.doi.org/10.1007/3-540-32202-7_1

Lee, H. L., T. H. Hertel, B. Sohngen, and N. Ramankutty. 2005. Towards an integrated land use database for assessing the potential for greenhouse gas mitigation. Global Trade Analysis Project (GTAP) Technical Papers, 25. Purdue ePubs, Purdue University. [online] URL: http://docs.lib. purdue.edu/. 
Lefroy, T., A. Curtis, A. Jakeman, and J. McKee, editors. 2012. Landscape logic: integrating science for landscape management. CSIRO Publishing, Collingwood, Victoria, Australia.

Leimbach, M., A. Popp, H. Lotze-Campen, N. Bauer, J. D. Dietrich, and D. Klein. 2012. Integrated assessment models: the interplay of climate change, agriculture and land use in a policy tool. Pages 204-229 in A. Dinar, and R. Mendelssohn, editors. Handbook on Climate Change and Agriculture. Edward Elgar Publishing, Cheltenham, UK.

Lengwiler, M. 2008. Participatory approaches in science and technology: historical origins and current practices in critical perspective. Science Technology and Human Values 33(2): 186-200. http://dx.doi.org/10.1177/0162243907311262

Lockie, S., G. Lawrence, and L. Cheshire. 2006. Reconfiguring rural resource governance: the legacy of neoliberalism in Australia. Pages 29-43 in P. J. Cloke, T. Marsden, and P. H. Mooney, editors. Handbook of Rural Studies. Sage Publications, London, UK. http://dx.doi.org/10.4135/9781848608016. $\underline{\mathrm{n} 3}$

Ludwig, D., M. Mangel, and B. Haddad. 2001. Ecology, conservation, and public policy. Annual Review of Ecological Systems 32: 481-571. http://dx.doi.org/10.1146/annurev. ecolsys.32.081501.114116

Marshall, G. R. 2009. Polycentricity, reciprocity, and farmer adoption of conservation practices under community-based governance. Ecological Economics 68(5): 1507-1520. http:// dx.doi.org/10.1016/j.ecolecon.2008.10.008

Matthews, R., N. Gilbert, A. Roach, J. Polhill, and N. M. Gotts. 2007. Agent-based land use models: a review of applications. Landscape Ecology 22(10): 1447-1459. http://dx.doi. org/10.1007/s10980-007-9135-1

McNeeley, J. A., R. A. Mittermeier, T. M. Brooks, F. Boltz, and N. Ash. 2009. The wealth of nature: ecosystem services, biodiversity and human well-being. International League of Conservation, Washington D.C., USA.

Mendham, E., and A. Curtis. 2010. Taking over the reins: trends and impacts of changes in rural property ownership. Society and Natural Resources 23(7): 653-668. http://dx.doi. org/10.1080/08941920801998893

Mendham, E., A. Curtis, and J. Millar. 2012. The natural resource management implications of rural property turnover. Ecology and Society 17(4): 5. http://dx.doi.org/10.5751/ ES-05071-170405

Millennium Ecosystem Assessment. 2005. Ecosystems and human well-being: synthesis. Island Press, Washington D.C., USA.

Minkler, M., V. B. Vasquez, M. Tajik, and D. Petersen. 2008. Promoting environmental justice through community-based participatory research: The role of community and partnership capacity. Health Education and Behavior 35(1): 119-137. http://dx.doi.org/10.1177/1090198106287692

Mooney, H., A. Larigauderie, M. Cesario, T. Elmquist, O. Hoegh-Guldberg, S. Lavorel, G. M. Mace, M. Palmer, R. Scholes, and T. Yahara. 2009. Biodiversity, climate change, and ecosystem services. Current Opinion in Environmental Sustainability 1(1): 46-54. http://dx.doi.org/10.1016/j. cosust.2009.07.006

Murray-Rust, D., N. Dendoncker, T. Dawson, L. AcostaMichilik, E. Karali, E. Guillem, and M. D. A. Rounsevell. 2011. Conceptualising the analysis of socio-ecological systems through ecosystem services and agent-based modelling. Journal of Land Use Science 6(2-3): 83-99. http:// dx.doi.org/10.1080/1747423X.2011.558600

Nelson, E., G. Mendoza, J. Regetz, S. Polasky, H. Tallis, D. R. Cameron, K. M. A. Chan, G. C. Daily, J. Goldstein, P. M. Kareiva, E. Lonsdorf, R. Naidoo, T. H. Ricketts, and M. R. Shaw. 2009. Modeling multiple ecosystem services, biodiversity conservation, commodity production, and tradeoffs at landscape scales. Frontiers in Ecology and the Environment 7(1): 4-11. http://dx.doi.org//10.1890/080023

Nelson, R., P. Kokic, S. Crimp, H. Meinke, and S. M. Howden. 2010a. The vulnerability of Australian rural communities to climate variability and change: Part I - Conceptualising and measuring vulnerability. Environmental Science and Policy 13(1): 8-17. http://dx.doi.org/10.1016/j.envsci.2009.09.006

Nelson, R., P. Kokic, S. Crimp, P. Martin, H. Meinke, S. M. Howden, P. de Voil, and U. Nidumolu. 2010b. The vulnerability of Australian rural communities to climate variability and change: Part II - Integrating impacts with adaptive capacity. Environmental Science and Policy 13(1): 18-27. http://dx.doi.org//10.1016/j.envsci.2009.09.007

Newig, J., V. Gaube, K. Berkhoff, K. Kaldrack, B. Kastens, J. Lutz, B. Schlußmeier, H. Adensam, and H. Haberl. 2008. The role of formalisation, participation and context in the success of public involvement mechanisms in resource management. Systemic Practice and Action Research 21(6): 423-441. http://dx.doi.org/10.1007/s11213-008-9113-9

Ninan, K. N. editor. 2010. Conserving and valuing ecosystem services and biodiversity: economic, institutional and social challenges. Routledge, London, UK.

Olsson, P., and C. Folke. 2001. Local ecological knowledge and institutional dynamics for ecosystem management: a study of Lake Racken watershed, Sweden. Ecosystems 4(2) :85-104. http://dx.doi.org/10.1007/s100210000061

Ostrom, E. 2009. A general framework for analyzing sustainability of social-ecological systems. Science 325 (5939): 419-422. http://dx.doi.org/10.1126/science.1172133 
Palm, C. A., S. M. Smukler, C. C. Sullivan, P. K. Mutuo, G. I. Nyadzi, and M. G. Walsh. 2010. Identifying potential synergies and trade-offs for meeting food security and climate change objectives in sub-Saharan Africa. Proceedings of the National Academy of Sciences of the United States of America 107(46): 19661-19666. http://dx.doi.org/10.1073/pnas.0912248107

Parrott, L., C. Chion, R. Gonzalès, and G. Latombe. 2012. Agents, individuals, and networks: modeling methods to inform natural resource management in regional landscapes. Ecology and Society 17(3): 32. http://dx.doi.org/10.5751/ ES-04936-170332

Parrott, L., and W. Meyer. 2012. Future Landscapes: Managing within complexity. Frontiers in Ecology and the Environment 10(7): 382-389. http://dx.doi.org/10.1890/110082

Paterson, S., and B. A. Bryan. 2012. Food-carbon trade-offs between agriculture and reforestation land uses under alternate market-based policies. Ecology and Society 17(3): 21. http:// dx.doi.org/10.5751/ES-04959-170321

Pearson, D. M., and J. T. Gorman. 2010. Managing the landscapes of the Australian Northern Territory for sustainability: visions, issues and strategies for successful planning. Futures 42(7): 711-722. http://dx.doi.org/10.1016/ j.futures.2010.04.008

Pedroli, B., T. Pinto-Correia, and P. Cornish. 2006. Landscape - what's in it? Trends in European landscape science and priority themes for concerted research. Landscape Ecology 21(3): 421-430. http://dx.doi.org/10.1007//10980-005-5226$\underline{\mathrm{Z}}$

Petter, M., S. Mooney, S. M. Maynard, A. Davidson, M. Cox, and I. Horosak. 2012. A methodology to map ecosystem functions to support ecosystem services assessments. Ecology and Society 18(1): 31. http://dx.doi.org/10.5751/ES-05260-180131

Polasky, S., E. Nelson, J. Camm, B. Csuti, P. Fackler, E. Lonsdorf, C. Montgomery, D. White, J., Arthur, B. GarberYonts, R. Haight, J. Kagan, A. Starfield, and C. Tobalske. 2008. Where to put things? Spatial land management to sustain biodiversity and economic returns. Biological Conservation 141(6): 1505-1524. http://dx.doi.org/10.1016/j.biocon.2008.03.022

Prell, C., K. Hubacek, M. Reed, C. Quinn, N. Jin, J. Holden, T. Burt, M. Kirby, and J. Sendzimir. 2007. If you have a hammer everything looks like a nail: traditional versus participatory model building. Interdisciplinary Science Reviews 32(3): 263-282. http://dx.doi.org/10.1179/030801807X211720

Rao, M., F. Guoliang, J. Thomas, G. Cherian, V., Chudiwale, and M. Awawdeh. 2007. A web-based GIS decision support system for managing and planning USDA's conservation reserve program (CRP). Environmental Modelling and
Software 22(9): 1270-1280. http://dx.doi.org/10.1016/j. envsoft.2006.08.003

Raymond, C. M., B. A. Bryan, D. Hatton MacDonald, A. Cast, S. Strathearn, A. Grandgirard, and T. Kalivas. 2009. Mapping community values for natural capital and ecosystem services. Ecological Economics 68(5): 1301-1315. http://dx.doi. org/10.1016/j.ecolecon.2008.12.006

Raymond, C. M., G. Brown, and G. M. Robinson. 2011. The influence of place attachment, and moral and normative concerns on the conservation of native vegetation: a test of two behavioural models. Journal of Environmental Psychology 31(4): 323-335. http://dx.doi.org/10.1016/j. jenvp.2011.08.006

Raymond, C. M., and J. Cleary. 2013. A tool and process that facilitate community capacity building and social learning for natural resource management. Ecology and Society 18(1): 25. http://dx.doi.org/10.5751/ES-05238-180125

Raymond, C. M., I. Fazey, M. S. Reed, L. C. Stringer, G. M. Robinson, and A. C. Evely. 2010. Integrating local and scientific knowledge for environmental management. Journal of Environmental Management 91(8): 1766-1777. http://dx. doi.org/10.1016/j.jenvman.2010.03.023

Reed, M. S. 2008. Stakeholder participation for environmental management: A literature review. Biological Conservation 141(10): 2417-2431. http://dx.doi.org/10.1016/j.biocon.2008.07.014

Robinson, G. M. 2008. Participation and stewardship: indicators of sustainability in two Canadian "environmental" programmes. Pages 185-202 in G. M. Robinson, editor. Sustainable Rural Systems: Sustainable Agriculture and Rural Communities. Ashgate, Burlington, Vermont, USA.

Rounsevell, M. D. A., B. Pedroli, K-H. Erb, M. Grumberger, A. G. Busck, H. Haberl, S. Kristensen, T. Kuemmerler, S. Lavorel, M. Lindner, H. Lotze-Campnen, M. J. Metger, D. Murray-Rust, A. Popp, M. Perez-Soba, A. Reenberg, A. Vadineanu, P. H. Verburg, and B. Wolfslehner. 2012. Challenges for land system science. Land Use Policy 29(4): 899-910. http://dx.doi.org/10.1016/j.landusepol.2012.01.007

Rounsevell, M. D. A., I. Reginster, M. B. Araujo, T. R. Carter, N. Dendoncker, F. Ewert, J. I. House, S. Kankaanpaa, R. Leemans, M. J. Metzger, C. Schmit, P. Smith, G. Tuck. 2006. A coherent set of future land use change scenarios for Europe. Agriculture, Ecosystems and Environment 114(1): 57-68. http://dx.doi.org/10.1016/j.agee.2005.11.027

Stacey, N., A. Izurieta, and S. T. Garnett. 2013. Collaborative measurement of performance of jointly managed protected areas in northern Australia. Ecology and Society 18(1): 19. http://dx.doi.org/10.5751/ES-05273-180119 
Steiner, F. 2008. The living landscape: an ecological approach to landscape planning. Second edition. Island Press, Washington D.C., USA.

Stobbe, T., G. Cotteleer, and G. C. van Kooten. 2009. Hobby farms and protection of farmland in British Columbia. Canadian Journal of Regional Science 32(3): 393-410.

Sullivan, P., D. Hellerstein, L. Hansen, R. Johanssen, S. Koenig, R. N. Lubowski, W. D. McBride, D. A. McGranahan, M. J. Roberts, S. J. Vogel, and S. Bucholz. 2004. The Conservation Reserve Program: economic implications for rural America. USDA - ERS Agricultural Economic Report, No. 834. [online] URL: http://dx.doi.org/10.2139/ssrn.614511.

Thackway, R., L. Lymburner, and J. P. Guerschman. 2013. Dynamic land cover information: bridging the gap between remote sensing and natural resource management. Ecology and Society 18(1): 2. http://dx.doi.org/10.5751/ES-05229-180102

Turner, B. L., II, E. F. Lambin, and A. Reenberg 2007. The emergence of land change science for global environmental change and sustainability. Proceedings of the National Academy of Sciences of the United States of America 104(52): 20666-20671. http://dx.doi.org/10.1073/pnas.0704119104

van Ittersum, M. K., F. Ewert, T. Heckelei, T., J. Wery, J. Allan Olsson, E. Andersen, I. Bezlepinka, F. Brouwer, M. Donatelli, G. Flichman, L. Olsson, A. E. Rizzoli, T. van der Wat, J. E. Wien, and J. Wolf. 2008. Integrated assessment of agricultural system: a component-based framework for the European Union (SEAMLESS). Agricultural Systems 96 (1-3): 150-165. http://dx.doi.org/10.1016/j.agsy.2007.07.009

Walford, N. S. 2003. Productivism is allegedly dead, long live productivism. Evidence of continued productivist attitudes and decision-making in South-East England. Journal of Rural Studies 19(4): 491-502. http://dx.doi.org/10.1016/S0743-0167 (03)00030-5

Waudby, H. P., S. Petit, and G. M. Robinson. 2012. Pastoralists' perceptions of biodiversity and land management strategies in the arid Stony Plains region of South Australia: implications for policy-makers. Journal of Environmental Management 112: 96-103. http://dx.doi.org/10.1016/j. jenvman.2012.07.012

Wiens, J. A., M. R. Moss, M. G. Turner, and D. J. Mladenoff, editors. 2007. Foundation papers in landscape ecology. Columbia University Press, New York, USA.

Wilson, A., J. Vickery, and C. Pendlebury. 2007. Agrienvironment schemes as a tool for reversing declining populations of grassland waders: mixed benefits from environmentally sensitive areas in England. Biological
Conservation 136(1): 128-135. http://dx.doi.org/10.1016/j. biocon.2006.11.010

Zander, K. K. 2013. Understanding public support for indigenous natural resource management in northern Australia. Ecology and Society 18(1): 11. http://dx.doi. org/10.5751/ES-05267-180111 